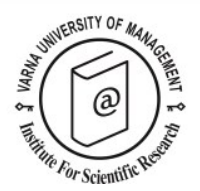

\title{
Connections between scientific research and education in the field of tourism and leisure in Russia
}

\author{
Anna Yu. Aleksandrova ${ }^{1}$ and Ekaterina V. Aigina ${ }^{2 *}$
}

Received: 29/07/2016 Accepted: 06/09/2016

\begin{abstract}
${ }^{1}$ Lomonosov Moscow State University, Leninskie Gory, 1, Moscow, 119991 Russia; tel/fax +7 4959 391555; email: analexan@mail.ru

${ }^{2}$ Lomonosov Moscow State University, Leninskie Gory, 1, Moscow, 119991 Russia; tel/fax +7 4959 391555; Email eaigina@yandex.ru

* Corresponding author
\end{abstract}

\begin{abstract}
This article focuses on the historical aspects of the development of tourism science and education in the USSR, and Russia as its legal successor. The specific features of their formation and organization in the second half of the twentieth century are examined, because they had a strong influence over the modern status of the country's tourism and recreation and development trends in the beginning of the twenty-first century. Scientific generalizations made in the article are based on a large amount of factual data analysis and original literary sources, and are followed by a number of concrete examples.
\end{abstract}

(C) 2017 Varna University of Management. All rights reserved

Keywords: tourism, leisure, recreation, research, education, Russia

Citation: Aleksandrova, A., E. Aigina (2017) Connections between scientific research and education in the field of tourism and leisure in Russia. European Journal of Tourism Research 15 pp. 75-91

The Union of Soviet Socialist Republics (USSR) was formed in 1922 as a result of Russian, Ukrainian, Belarussian and Caucasian republics joining together. With the territory taking up more than one-sixth of the Earth's surface, the USSR was the biggest country in the world. It extended approximately $10,000 \mathrm{~km}$ from west to east (through 11 time zones) and more than $7000 \mathrm{~km}$ from north to south. There were five climatic zones within the country. The USSR had the longest frontier in the world (more than $60,000 \mathrm{~km}$ ).

After World War II, the USSR, as well as the US, were superpowers. The USSR had huge political, economic and military power, and headed one of the most powerful (equally with NATO) military blocs: the Warsaw Treaty Organization. The Soviet Union had a leading position in the world socialist system. The country was a UN Security Council permanent member.

In Soviet history, the period 1987-91 is known as perestroika ('restructuring'). It was directly connected with Mikhail Gorbachev, the General Secretary of the Communist Party Central Committee, who declared a new course in state development and initiated profound changes in all spheres of Soviet society. Perestroika can be conditionally divided into three periods: 
- The first period (March 1985 to January 1987) was called 'acceleration'. This period was characterized by the admission of some drawbacks of the existing Soviet political and economic systems and with some attempts to improve them with the help of several large administrative campaigns (for example, an alcohol-free campaign). There were no radical reforms in that period, though many representatives of Soviet administration were replaced by new executives.

- The second period (January 1987 to June 1989) was the beginning of large-scale reforms. An attempt to reform socialism into democracy was made. The policy of 'glasnost' ('openness') was proclaimed in public life. Private property became legal in the economy and the first joint ventures with foreign companies were formed. In foreign policy, 'new thinking' aimed at improving international relations with Western countries became the main doctrine. Along with these reforms, general instability increased, the economic situation changed for the worse, ideas of separation emerged in national regions and the first national conflicts took place.

The third period (June 1989 to December 1991) was characterized by a crucial destabilization of the political situation within the country and the expansion of a large-scale economic crisis. As a replacement for socialism, creating a democratic society and a market economy was undertaken. The USSR lost its superpower status and other important positions worldwide. Inside the country, Soviet republics started to adopt declarations on state sovereignty. The elimination of the Communist Party and the breakdown of the USSR were the expected results of these events.

Officially, the USSR crashed on 26 December 1991. The Russian Federation is its legal successor.

\section{The connections between scientific research and education in the field of tourism and leisure}

Scientific and educational activities in the field of tourism and recreation in Russia have appeared at the same time, being inseparably linked to organization of first trips. From a historical perspective, the generation of special scientific knowledge and its distribution through the system of education had several stages, which differ in forms, mechanisms and integration.

The Russian school of tourist studies started at the end of the nineteenth and the beginning of the twentieth century. At that time there was a fashion for mountain trips, which came from Western Europe, and the first mountain clubs according to the Alpine societies' model were created. For example, the Russian Mountain Society was founded in 1900 in Moscow, and was aimed at large-scale mountain studies and distribution of knowledge about their nature through mountain trips, excursions and climbing. World-famous Russian scientists (such as D.N. Anuchin, V.I. Vernadsky and V.P. Semenov-Tyanshansky, to name a few) took part in the work of the society. They combined scientific and educational activities, and presented public lectures about the nature of mountain regions in Russia. The society published its yearbook, including the articles mainly of journalistic character, but also some scientific and analytical studies.

About the same time, the connection between scientific research and educational activities in excursions and sightseeing started to strengthen. In Russia, excursions appeared at the end of the eighteenth to the beginning of the nineteenth century. Reports on excursions presented by the teachers became the first educational supplies on regional studies, due to their content and availability. During the nineteenth century, excursions became an essential part of the school educational process. Methodical assistance in school excursions was primarily provided by educational magazines and then by special periodical publications (such as the Russian Excursionist, the Excursion Bulletin and so on). At the beginning of the twentieth century, valuable books of methodical character based on scientific principles (for example, the Schkolnije ekskursii, 1910) appeared. Schematic excursion plans for the whole period of school education and school excursion methods had been worked out and discussed at pedagogical congresses and meetings. At the end of the nineteenth to the beginning of the twentieth century, the first cultural and enlightening excursions began. In this period 
many outstanding Russian scientists (such as D.I. Mendeleev, N.M. Przhevalsky, K.A. Timiryazev and I.P. Pavlov, to name a few) played important roles in developing these excursion activities. In 1907 in St Petersburg the first courses for training excursionists, mainly for school teachers, opened.

As a result, from the very beginning, the connection between scientific research and educational activities in the field of tourism and leisure could be seen as a joint solution to educational and partly methodical questions. The participation of the top scientists in this process showed the importance of this work within the country.

The twentieth century introduced a worldwide tendency to concentrate a major part of fundamental science, vast applied studies and works in universities. But in the USSR they were mainly concentrated in the Academy of Science, departmental branch institutions and design offices. Under these conditions, high school was no longer the main centre of fundamental scientific research, whose role was underestimated. In spite of the formal division of science and education that could be seen in institutional, executive, regulative and financial separation of these spheres, there were, on the contrary, some considerable examples of objective necessity for their coordination and intention for integration in the field of tourism and recreation, in particular.

Within one of the most numerous Soviet organizations - trade union tourism - the Institute for Higher Qualification of Specialists in Tourism and Excursion existed. It was aimed at improving skills and knowledge of almost all the categories of staff in the field of tourism and hospitality - from top tourism management, executive personnel and tourist guides, to supporting catering and room-service staff. There was a special methodical department in the institute responsible for diverse methodical and educational materials for the students (for example, Aleksandrov, 1974; Drogov et al., 1983, Katznelson, 1977; Kachanov, 1988; Lukoyanov, 1977; Pasechniy et al., 1980, Podgotovka et al., 1982, Schturmer, 1980). The connection between science and education in the field of tourism and recreation was fixed structurally.

Another model of integration was presented by the USSR Academy of Science and certain universities. In 1975 in the USSR Academy of Science Institute of Geography a monograph, Theoretical Foundations of Recreational Geography, edited by V.S. Preobrazhensky, was published. The monograph established a new special branch in geography dealing with spatial organization and types of human activities aimed at restoration and development of their physical and mental abilities: recreational geography. The basic concept of the spatial recreational system was put forward in the monograph, and served as a starting point for future investigations in recreational geography (for example, Geografia recreatsionnih system v SSSR, 1980; Territorialnaya organizatsiya otdyha naseleniya Moskvy i Moskovskoi oblasti, 1986; Recreatsionnyje systemy, 1986; Recreatsionnaya geografia, 1983; Recreatsionnyje resursy SSSR, 1990), and was highly appreciated by the geographical community within the country and abroad. Recreational geography as an educational course has been included in the academic system of education. In particular, it was included in Lomonosov Moscow State University (MSU), Faculty of Geography educational plan, where the corresponding specialization was lately opened.

MSU geographers have taken part in theoretical and applied recreational research organized by the USSR Academy of Science Institute of Geography. They have prepared educational materials where basic knowledge on recreational geography has been presented and expanded (for example, Mironenko, Tverdokhlebov, 1981; Recreatsionnyje systemy, 1986). Also, a number of dissertations on tourism and recreation have been written.

In the beginning of the twenty-first century, the need to deepen the interconnection between science and education has been acknowledged in Russia. In the scientific community, as well as in governmental structures, there is an increased interest in integrative studies and in new, more complicated models of integration. 
The strategic direction of Russian schools of tourism studies corresponds with the global scientific trend based on the interdisciplinary synthesis of knowledge. Whereas in Western countries, tourism studies have been institutionalized as an independent branch of science, in Russia, the arrangement of tourism studies into an independent discipline is still in its very beginnings. This can be proved by discussions on principles and subject areas of a multidisciplinary system research in tourism and on the name of a new scientific discipline (Zorin and Kvartalnov, 2001; Okishev, 2005; Dolzhenko, 2010).

The proposed direction for tourism studies development has been acknowledged in professional tourism education. In 2004 the Russian Ministry of Education established a new educational specialty 'Tourism' based on a systematic interdisciplinary approach. All the country's scientific and educational communities took part in its creation. This new educational program included the study of a number of learning cycles: humanities, social and economic cycles, natural science and professional disciplines, as well as conducting training and work practices. It was intended to teach competent specialists that are ready to carry out projects, as well as productive and technological, administrative and managerial, service and scientific activities in the field of tourism (Federalnyi obrazovatelnyi standart, 2009). Within the frameworks of the professional learning cycle students obtain knowledge, skills and experience in tourism resources, tourism management and marketing, law systems in tourism, information technologies in the tourism industry, tourism projects and so on. Recently, a tendency to move from narrow to broad specialization in teaching highly educated and highly qualified specialists for the tourism industry has been outlined. The exponential growth of scientific knowledge in the field of tourism and recreation provides favourable opportunities for the development of professional tourism education.

\section{Political, economic, social and technological factors that have influenced and still influence scientific research and education in the field of tourism and leisure}

The progress of scientific research and education in tourism and leisure in Russia is characterized by a number of factors. We can point out the group of basic factors - political, economic, social and technological - that have a cross-sectional nature. Yet the contents, strength and direction of their influence have radically changed in the last fifty years.

In the USSR, the role of political and ideological factors in all spheres of society has been extremely high. In tourism and recreation, the scientific and educational community, separated by the 'Iron Curtain', was artificially isolated from the international scientific ideas and major trends in tourism education development. There was some cooperation in tourism and recreation scientific research and education between the USSR and socialist countries, but any attempts to establish cooperation with colleagues from capitalist countries were limited or even stopped. The situation was forced down by tough ideological control when the topics of scientific research, and the whole educational system were determined by ideological priorities.

Starting in the middle of 1980s, the course for reforms of the totalitarian system - perestroika - led to essential changes in the life of the country and the whole world. Under new conditions, mainly in the very beginning of the reforms, political factors played a massive stimulating role in scientific and educational activities in the field of tourism and recreation. The fall of the 'Iron Curtain' and democratic processes in the society vitally connected with market relations growth led to the boom of inbound and outbound tourism. The number of tourism enterprises has grown rapidly. The need for the theoretical explanation of the current situation as well as the need to teach professionals for the tourism industry appeared in a very short time.

The influence of political factors remained until the 2000s. During the formation of a state power system and the strengthening of executive institutions in Russia, the position of the state has grown, particularly in the determination of professional tourism education policy and in working out educational standards. 
Economic factors are also very important for the development of scientific research and education in tourism and recreation. In the USSR there was a planned economy. Planning covered all branches of the economy, including tourism. Thus, the period of the 1970s to the 1980 s in tourism development was regulated and planned. These plans were worked out in higher governmental spheres and were given to tourism enterprises and organizations. The main guidelines for tourism development in the USSR were established by special normative documents - decrees. The decrees were adopted by the Communist Party Central Committee (the top party organization in the periods between the Communist Party Congresses) together with the Council of Ministers (the top executive and administrative governmental body) and All-Union Central Council of Trade Unions (the top trade union body in the periods between the USSR Trade Union Congresses). These decrees were obligatory for implementation for all tourist organizations and enterprises in the country. Their realization was strictly controlled by the state and trade union organizations.

For example, the Decree of the Communist Party Central Committee, the USSR Council of Ministers and All-Union Central Council of Trade Unions issued on May 30, 1969 'On Measures for Further Development of Tourism and Excursions in the Country' gave the order to start working out projects for regional planning of recreational zones and standard projects of tourism and recreational enterprises for different climatic areas of the country from 1970. In order to fulfill this decision, a number of scientific institutions were given certain tasks to carry out works. The Decree of the Communist Party Central Committee, the USSR Council of Ministers and All-Union Central Council of Trade Unions issued on October 31, 1980 no. 983 'On Further Development and Improvement of Tourism and Excursion Activities in the Country' pointed out the necessity to expand and improve the system of tourism personnel education and therefore to establish the Institute for Higher Qualification of Specialists in Tourism and Excursions. It was planned to increase the number of trained tourist organizers, tourist public instructors and tour managers to
300,000 per year. According to established standards, every person employed in tourism had to improve their qualifications not less than every two years.

The planned economy was replaced with a market economy during the reforms in the 1990s. In this period, the development of the Russian educational market had a very controversial character. On the one hand, it was a time when the modern system of continuous professional tourist education began to form. Many higher educational institutions, both state and private, responsible for tourism industry professional personnel supply were established. They started to train a new generation of employees capable of carrying out executive and financial activities in the field of tourism and hospitality. Also, international experience was widely used. However, it is difficult to identify a steady orientation to a certain foreign educational model in Russian tourism education. It has been influenced by English and German schools, and now the French educational system is becoming more widely used. However, this does not mean that these methods can be brought to Russia without any comprehension or without taking into consideration educational and cultural differences. The attempts to just copy foreign experience have proved to be unproductive.

On the other hand, a rapid growth of market relations in tourism in this period was followed by some functional imbalance. There was an obvious distortion towards the training of tourism managers. Two-thirds of specialized educational programs were carried out within the frameworks of tourism management training. Another disproportion occurred in the rapid growth of the number of educational enterprises lacking the necessary methodical level and technical basis, and in the domination of higher education over special secondary education in tourism. From 1996 to 2011 the number of higher and secondary specialized educational institutions teaching staff for tourism industry increased sevenfold. The building of educational structures in tourism contradicted the situation in Russian scientific schools of tourism studies. The development of tourism studies in Russia lagged behind 
tourism education growth; whereas in Western countries it was ahead or went synchronically with tourism education improvement. This explains why the theme of professional tourism education prevailed at that time. At the same time, the release from Soviet scholastic schemes in science gave a new quality to tourism studies. In the 2000s, existing disproportions were eliminated or diminished thanks to state regulation.

Social factors have always had, and still have, a noticeable influence on scientific research and education in the field of tourism and recreation. The amateur tourism movement was very popular in the USSR. There are hardly any other countries with such a large amount of non-commercial tourist trips organized by amateur tourists using their money and free time. Starting in the middle of 1950 s, tourist gatherings, including contests in tourism skills and compass reading, became regular. Lately, tourist units and clubs have started to emerge in many industrial enterprises and educational institutions. In the middle of the 1980s, about 20-30 million tourists were involved in amateur tourism (Sokolova, 2002, p. 307). There were more than 800 tourist clubs. As a result of this massive long-time movement of the whole army of active tourists, together with the staff of tourist, sport and trade union enterprises, annual tourist championships started in 1981, and the decision to organize regular all-union tourist assemblies was taken.

Tourist clubs were responsible for the creation and development of routes for independent tourists in the country. The persons responsible for the routes and types of tourism provided independent tourists with the necessary methodical materials and consultations. For example, in the 1970s, the city tourist club in Leningrad had a collection of 3500 reports about independent travels made by its members in different parts of the country, and had more than 6000 books on tourism, regional studies, tourism methodology and so on (Usyskin, 2000, p. 202). Tourist clubs were responsible for educational activities, training instructors for weekend trips. Their activities were supervised by trade unions.
In the 1990s, under system crisis and USSR disintegration, the independent tourism movement was about to vanish. In post-reform Russia, the impact of social factors can be seen in the establishment and operation of a number of diverse non-governmental tourist organizations; for example, an association of journalists, specializing in tourism or branch business associations. Along with these groups there was a non-governmental union of scientists for joint research and legislative initiatives in tourism: the National Academy of Tourism. This scientific and methodological centre coordinates, develops and executes fundamental and applied research in the field of tourism. There are more than 800 full members in the academy now, representing 40 regions of Russia. The representatives of almost all higher educational institutions teaching staff for tourism, as well as many top tourism executives and administrators, are National Academy of Tourism members. More than 70 per cent of academy members have scientific degrees (http://www.nat-moo.ru/about.html).

If we consider other issues that have an impact on scientific and educational activity in tourism and recreation, we should point out technological factors. During the period of the 1970 s to the 1980s, their influence could be seen first of all in the large-scale construction of holiday homes, pensions and hostels. Showing the advantages of the Soviet way of life, the state was conducting its social policy aimed at providing broad access to tourist resources for all working people. This, undoubtedly, can be considered as one of the Soviet achievements. The plans to increase the social tourism scales were linked to the scientific and research activities, as well as to the plans for teaching and further training of staff for tourism.

In modern Russia, the impact of technological factors on scientific and research activities is increasing. The emergence of principally new information and communication technologies, starting with the Internet, has formed a new model in education, and for tourism education in particular. Tourism education is no longer limited by spatial, temporal and institutional boundaries; remote forms of tourism education have become more widespread. Nowadays, in 
training staff for the tourism industry in Russia, the following remote educational technologies are used: case technologies, Internet technologies and telecommunications (technologies using satellite information). The information technology revolution shows the need to turn to the continuing education system. In the tourism and recreation sphere in Russia, it is implemented, for example, with the help of diverse additional educational programs. If compared with the Soviet period, the present education in tourism is aimed not so much at the assimilation of knowledge, as at the possibilities to operate it. Besides, the information process forms the context of any scientific research in the field of tourism and recreation, and modern information and communication technologies provide rapid scientific information exchange.

\section{The drivers in science and education that have contributed to the development of the field of tourism and leisure}

Different drivers, mainly in science, have contributed to the development of tourism and recreation in the USSR, and in Russia in particular. The development of science is characterized by two inseparably linked but basically opposite processes: differentiation (separation of new scientific disciplines) and integration (synthesis of knowledge, association of sciences into a single unit; annihilation of boundaries between them). Differentiation prevails in some periods of scientific development; integration dominates in other periods. The second half of the twentieth century - the period of scientific and technical revolution - is considered to be the most important period of science differentiation. It was a turning point of scientific development in general. The revolution has put forward absolutely new fundamental problems, and required more profound penetration in the objective world that stipulated further specialization of scientific knowledge. Deep transformations in cognition, principles and methods of scientific activity have taken place.

In this time in the USSR, scientific disciplines aimed at studying tourism and leisure organization started to be set apart from various sciences. Recreational geography as an economic geography branch, recreational architecture and urban development, tourism economy and leisure sociology were shaped; the Soviet school of balneology as a branch of medicine was developed. Their arrangement was essentially important for rapidly growing tourism and recreation activity in the USSR, as it has become science based.

Traditionally, an amount of studies on tourism and leisure spatial organization have been carried out by research and design institutes of the state committee for civil engineering and architecture, a division of the USSR State Construction Committee (Gosstroy). They were involved in designing therapeutic and resort facilities, tourist complexes, cultural and leisure services, natural resorts and protected areas. In the Soviet period, a whole network of scientific and research institutes was established, responsible for the investigation and study of the USSR resort assets, for working out advantages and disadvantages for their application in the treatment of ill people, for methods of complex resort therapy and regulations for mineral water and other resort facilities' maintenance and so on.

The process of differentiation went along with the tendency for integration of scientific disciplines. Even though a complete assembly of leisure sciences (also known as recrealogy science) has not been formed yet, the question on specific scientific trend in researching mass tourism and leisure in the USSR - about the recrealogical science cycle - has been put forward in Soviet literature (Teoreticheskiye problemy, 1989, pp. 7-22). The situation of the late 1960s - in which a general socio-cultural background and scientific situation formed in the beginning of the scientific and technical revolution - promoted its appearance. At that time, cybernetics, synergy and ecology burst into the human mind.

An extensive distribution of a system approach in science has greatly influenced the recreational science cycle arrangement. In the USSR from the 1960s to the 1980s it served as a methodological basis for investigation of the fundamental regulations for tourism and leisure organization. In 1969 a hypothesis on recreational activity system character was proposed (see Geograficheskiye problemy, 
1969), and in the beginning of the 1970s a basic model of spatial recreational system (SRS) was worked out. SRS is a social geographical system consisting of the following interconnected subsystems: a group of recreating people; natural and cultural complexes; technical (engineering) constructions; supporting staff; and an administrative body. SRS is characterized by functional and spatial unity (see Figure 1). The system characteristics of SRS can be identified by the following links formed by SRS elements (Table 1).

The SRS hypothesis turned out to be very productive. Works on SRS detection started in different parts of the country. A number of scientific institutes have tasks projecting and elaborating scientific and technical documents for SRS construction. Elaboration of tourism and leisure development strategy within the country, as well as SRS administration and the forecast of their growth and so on, have a scientifically approved basis.

Before the SRS, various system models, for example, landscape, were used in Soviet science to characterize the natural potential of a territory and its application for tourism and recreational needs. The SRS model was principally different because of its anthropocentric character: a human being was the core object in this system. Consequently, from the very beginning, the recreational science cycle in the USSR was formed within the framework of humanization - a key scientific development trend. SRS principles revealed the turn to human needs, all spheres and cycles of human activity. The change from

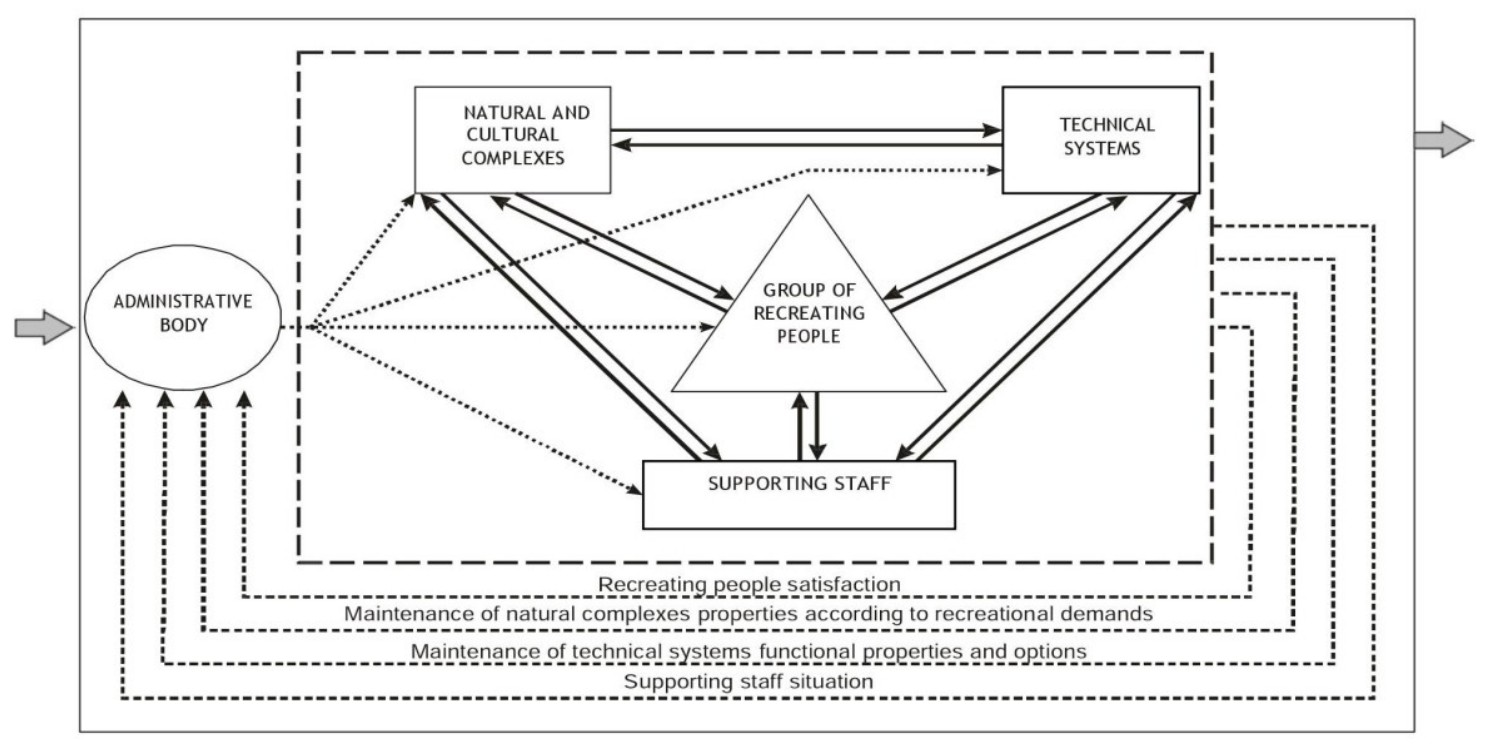

Figure 1. Spatial recreational system

Source: Teoreticheskiye osnovy (1975)

GRP - group of recreating people

$\mathrm{NCC}$ - natural and cultural complexes

TS - technical systems

SS - supporting staff

$\mathrm{AB}$ - administrative body

- system's external communications

- communications between subsystems

.... - management actions

- information about subsystems' state:

I - recreating people satisfaction

II - maintenance of natural complexes properties according to recreational demands

III - maintenance of technical systems functional properties and options

IV - supporting staff situation. 
Table 1. System characteristics of spatial recreational systems

\begin{tabular}{|c|c|c|c|c|c|}
\hline \multirow[t]{2}{*}{ Subsystem } & \multicolumn{5}{|c|}{ Subsystem characteristics } \\
\hline & $\begin{array}{l}\text { Group of } \\
\text { recreating } \\
\text { people }\end{array}$ & $\begin{array}{l}\text { Natural and } \\
\text { cultural } \\
\text { complexes }\end{array}$ & $\begin{array}{l}\text { Technical } \\
\text { systems }\end{array}$ & $\begin{array}{l}\text { Supporting } \\
\text { staff }\end{array}$ & $\begin{array}{l}\text { Administrative } \\
\text { body }\end{array}$ \\
\hline $\begin{array}{l}\text { Group of } \\
\text { recreating } \\
\text { people }\end{array}$ & & $\begin{array}{l}\text { Quantity, } \\
\text { comfort } \\
\text { sustainability } \\
\text { attractiveness }\end{array}$ & $\begin{array}{l}\text { Variety } \\
\text { Quantity } \\
\text { Comfort }\end{array}$ & $\begin{array}{l}\text { Professional } \\
\text { skills }\end{array}$ & $\begin{array}{l}\text { Information } \\
\text { access }\end{array}$ \\
\hline $\begin{array}{l}\text { Natural and } \\
\text { cultural } \\
\text { complexes }\end{array}$ & $\begin{array}{l}\text { Rhythmicity } \\
\text { Selectivity }\end{array}$ & & $\begin{array}{l}\text { Environment } \\
\text { friendliness }\end{array}$ & $\begin{array}{l}\text { Regulation } \\
\text { Restoration }\end{array}$ & $\begin{array}{l}\text { Regulatory } \\
\text { support }\end{array}$ \\
\hline $\begin{array}{l}\text { Technical } \\
\text { systems }\end{array}$ & Homogeny & $\begin{array}{l}\text { Resource } \\
\text { assessment } \\
\text { Reliability }\end{array}$ & & $\begin{array}{l}\text { Availability } \\
\text { of labour } \\
\text { resources } \\
\text { Employment }\end{array}$ & $\begin{array}{l}\text { Capital- } \\
\text { labour ratio }\end{array}$ \\
\hline $\begin{array}{l}\text { Supporting } \\
\text { staff }\end{array}$ & Technology & Comfort & $\begin{array}{l}\text { Capital-labour } \\
\text { ratio }\end{array}$ & & Prophylactics \\
\hline $\begin{array}{l}\text { Administrative } \\
\text { body }\end{array}$ & Equity & Hygiene & $\begin{array}{l}\text { Occupation rate } \\
\text { Technologically } \\
\text { prepared } \\
\text { equipment }\end{array}$ & Qualification & \\
\hline
\end{tabular}

a natural-resource paradigm to a social one had revolutionary consequences, not only for recreational science cycle development, but also for the humanistic paradigm of Soviet science in general. For a long time there was insufficient attention paid to social problems in Soviet science. For example, in geography, research on spatial processes and organizational forms of human activity and public production from the human standpoint human work, living, leisure conditions, personal development and reproduction - started only after SRS theory appeared. These questions have found expression in social development programs improving the living conditions of the population, as well as in programs of tourism and recreation development in the USSR and its socialist republics.

The SRS model developed under state administrative system conditions with public economy centralized planning. In the initial scheme, SRS actions were set by directive prescriptions of administrative bodies based on a normative approach. In real life, the mistakes made in decision making led to troubles in SRS functioning. After some time, the SRS model drawbacks became obvious for its authors. 
For a long time we considered this [recreational] model to be like technical ones in their management, strictness and automatism, tough determinism or stochastic relations, automatic reverse links and renunciation from recreating people. Now it is clear that we need a different logic, all self-organization levels and primarily the human character of the system taken into account (Preobrazhensky, Kvartalnov, 1989, p. 20).

Another particular feature of scientific research and education in tourism and recreation in the Soviet period is their strong ideological content. The subjects for tourism research were completely determined by the ideological priorities of the Soviet science in general. That caused, in particular, special attention to be paid to the social tourism phenomenon. In the tourism works published during the 1970s to the 1980s in the USSR, it was regarded as an expression of human rights to rest and have cultural free-time - which is the opposite to tourism in capitalist countries, which was praised as a class privilege. One of the specific features of tourism analysis in the USSR shows that it was considered within the frameworks of state propaganda and agitation tasks. Tourism was described as a significant means for the 'communist upbringing of the workforce' and one of the main channels of the 'Soviet way of life propaganda' (for example, Kvartalnov 1986; Dvornichenko 1985). In 1976 a special problem scientific and research laboratory aimed to study foreign tourists as carriers and distributors of information about the USSR was formed in the head department on foreign tourism of the USSR Council of Ministers (for example, Dolmatov, 1976; Fisenko, 1978; Fedotova, 1980). Even though these works had a rather profound character, they were still subjected to propaganda interests.

Ideological reasons penetrated the whole system of education for tourism and recreation. Special attention has always been paid to teaching guides and interpreters, because they were at the front line of ideological battle with the capitalist countries. Their work has been controlled by special methodical councils established by the city Communist Party committees.
As a result, the arrangement of Soviet research and teaching school in the field of tourism and recreation had a complicated and controversial character. On the one hand, the foundations providing the scientific development of the USSR's tourism industry have been formed; some of them are still up to date. On the other hand, the slowdown of all truly scientific social studies, mainly in the Stalin period, had negatively influenced not only USSR science, but the entire social sphere, including tourism and leisure.

The extent that questions of innovation, quality and cooperation have been researched in science and education

The achievements of Soviet science, including fundamental and applied works, were impressive in a number of spheres. Nuclear energy, spaceship construction and space explorations have brought well-deserved respect for Soviet science and techniques. The works of Soviet physicists and chemists awarded Nobel prizes have become world famous. But the major part of scientific and technical potential of the country has been concentrated in the defence complex. Its high secrecy, as well as the thick cover of secrecy over all Soviet society in the Cold War atmosphere, made the possibilities of innovation studies very limited. Nevertheless, there was a problem widely discussed in science in that period: the problem of the practical application of brilliant achievements of the Soviet scientific and engineering community in the national economy. The system of economic relations formed in the USSR was insensitive to scientific and technical achievements. Special measures for their forced application in the national economy were required.

A similar problem existed in education. Acceleration of scientific and technical progress caused complications in school programs. Pupils had difficulties understanding their program of study that sometimes led to the decrease of interest towards lessons and to the reduction of the knowledge level. Innovative teachers were searching for ways to solve these problems, and some got brilliant results in training and educational work (V.A. Sukhomlinsky, V.F. Shatalov, E.I. Ilyin and 
others). However, extensive application of their innovative methods was almost impossible. There was a need for an essential transformation of the whole educational system. Starting in 1984, the reform of education was not organized properly and ended quickly.

The questions of quality in science and education have been raised sporadically. The burst of pedagogical activity came in the 1960s during the educational reform in the USSR. A wide range of questions connected with the quality of education was discussed at that time: qualification of teachers, quantity of school literature, the essence of the teaching method, the organization of the teaching process, material and financial support of education, the connection between education and present life, demands of 'communist development' and so on. At the same time, questions of quality in science have also been discussed, particularly after the Decree of the Communist Party Central Committee and the USSR Council of Ministers no. 760 'On the Measures for Increasing the Efficiency of Scientific Organizations and Acceleration of Scientific and Technical Achievements Utilization' published on 24 September 1968. The next time large discussions occurred on problems of quality in science and education was at the end of the 1990s to the beginning of the 2000s. It was also connected with the reforms in the scientific and educational systems of Russia.

In the USSR, the questions of cooperation in science and education have been studied widely, but mainly within the socialist system framework. Soviet scientists turned to them in 1950s. The creation of the Council for Mutual Economic Assistance (CMEA) - an intergovernmental economic organization of the socialist countries - in 1948 made a push for it. The CMEA was the main international body for the socialist countries' integration in science. Investigation of the laws of world socialist system formation and development, as well as the socialist countries' cooperation in different spheres, were considered to be the most important scientific and political tasks.

During the first period, a limited source base, and a lack of scientists of appropriate specialization, were the reasons for the lack of numerous and superficial works. They showed certain facts of cooperation in order to get their reader acquainted with the main achievements of the socialist countries, and creatively used the Soviet experience. A new period in scientific cooperation started after the agreement was signed between the USSR Academy of Science and academies of the socialist countries in 1957-58. The corresponding issues have become regular for a number of scientific and research institutes of the USSR Academy of Science. Their investigations had a compound character. They showed the diversity of forms and directions of scientific cooperation. Special attention was paid to the communist ideas propaganda and to the communist world viewpoint that had a decisive influence over methodological changes in science in socialist countries. At the end of the 1970s to the beginning of the 1980s, the complete collective works on the results of bilateral and multilateral cooperation of the USSR and the socialist countries in science and culture with new tendencies and regularities discovered in this sphere were published. Numerous facts given in the works of Soviet scientists confirm the substantial amount of scientific cooperation between the USSR and the socialist countries on the level of academies, institutes and other scientific establishments.

Significant contribution to socialist integration has been made by higher educational enterprises of the countries - members of the CMEA. Their international experience was the subject of special research in the USSR. Modern High School - the international publication of the socialist countries in Russian - discusses the questions of teaching, improvement of educational process, forecasts for higher education development and economy, scientific and research activities and further staff training. Its numerous publications helped in strengthening cooperation of the socialist countries in working out the scientific foundations of higher education.

The cooperation that existed and/or still exists between central and eastern European countries in the field of tourism and leisure science and education 
Cooperation between central and eastern European countries in the field of tourism and leisure science and education was subjected to the general principles of socialist integration. It was carried on within the frameworks of Complex Programs for Further Cooperation and Development of Socialist Economic Integration of the CMEA countries that foresaw cooperation in science and education, as well as within the intergovernmental agreements on scientific and cultural relations and interagency agreements of the socialist countries.

Cooperation between central and eastern European countries in the field of tourism and leisure has come a long way, starting from the first contacts to the finally established bilateral and multilateral cooperation. Many forms and directions of international cooperation continue to exist nowadays, and have found new ways of growth and succession in the following period.

Direct links between scientific institutions, higher educational enterprises, individual scientists and lecturers in tourism and recreation of the URSS and central and eastern European countries started to form in the first half of the 1970s. Their arrangement went by means of correspondence, organization of the first international scientific forums and study tours for specialists.

The mutual exchange of scientists and lecturers was one of the forms of cooperation between the USSR and the socialist countries. The study tours on a currency-free basis spread widely at the beginning of cooperation, and have been lately substituted by long-term internships. They often resulted in theses for scientific degrees (for example, Mironenko, 1973; 1987). The USSR has paid serious attention to providing the socialist countries with the necessary support in the education of competent specialists. The scientists from central and eastern European countries have successfully presented their theses for scientific degrees in the USSR, in the field of tourism and leisure as well (for example, Vodenska, 1978).

Mutual exchange in information, special literature and other materials is one more form of cooperation between the USSR and the socialist countries in the field of tourism and leisure. Works of Polish, Bulgarian, Czechoslovakian and Yugoslavian scientists were generally known to Soviet scientists. The achievements of the Polish school of tourism and recreation studies (M.I. Mileska, J. Warszynska, O. Rogalewski and others) were highly appreciated in the USSR. The Bulgarian school of tourism and recreation studies was primarily associated with the works of the Department of Tourism Geography, the Institute of Geography, University of Sofia (L. Dinev, M. Bachvarov) and the Higher Economic Institute in Varna (N. Apostolov). The works of Czechoslovakian scientists on tourism development factors in Slovakia (P. Mariot) and about tourism growth in the Jesenice region (S. Šprincova) raised interest among the Soviet specialists. In Yugoslavia the works of $Z$. Jovicic from the Belgrade University, Institute of Geography research centre were highly appreciated.

In the same period, the specialists in tourism and recreation from the central and eastern European socialist countries were acquainted with the works in the corresponding areas held in the USSR. They were presented at international conferences, issued in specialized publications (for example, Vedenin, 1977; Mironenko and Tverdokhlebov, 1981 and others). In 1981 the first textbook on recreational geography in the USSR was published in Moscow State University (Mironenko and Tverdokhlebov, 1981) and it was recognized not only within the country, but also by the specialists in the Central and Eastern European countries. A review of this book was published in Bulgaria.

At the same time, the first attempts to translate and publish foreign books on tourism and recreation studies were made. In 1974 a monograph by J. Giezgała, 'Turizm v narodnom hozyaistve', was published in Russian, introducing theoretical approaches to economic analysis of tourism industry and the possibilities of using econometrical methods and mathematical modelling techniques in the tourism economy. In the same year a collective monograph, 'Territorial Natural Recreational 
Resources of Bulgarian Black Sea Coast', was translated into Russian.

Intensive and increasing with time, the mutual exchange of literature in the field of tourism and leisure has allowed the creation of specialized book funds. In the USSR they have been formed, in particular, in the main national library - the USSR State Lenin Library (since 1992 the Russian State Library) and are still requested by readers.

Eventually there was a transformation from simple international links to more diverse and complex forms of cooperation. The USSR, together with the European socialist countries, started to coordinate scientific research and to carry out joint studies in the field of tourism and recreation. Temporary international research groups for joint scientific research were created. This helped to develop the topics and methods of studies in tourism and recreation. The results of joint research frequently served as a foundation for monographs presented by international authors (for example, the joint Soviet-Bulgarian monograph, 'Recreatsionnyje systemy', Moscow, 1986), where the results of bilateral cooperation in tourism and recreation studies were summarized. International relations between the USSR and the European socialist countries were aimed at convergence and unification of educational contents, methods and forms and for improvement of teaching and educational work organization with this.

All the forms of cooperation mentioned above are still relevant. Along with them, more complicated forms of cooperation, such as joint international educational programs with two diplomas, have been implemented within the frameworks of Russian and foreign universities partner projects.

\section{The cooperation existed and/or still exists between Central and Eastern European countries with Western European ones in the field of tourism and leisure science and education}

The basis for long-term cooperation between the USSR and Western European countries in the field of tourism and leisure science and education was formed at the beginning of the 1970s. It started in the form of international scientific meetings and joint scientific publiccations. In 1972 a Working Group on Tourism Geography was formed within the International Geographical Union. It united leading scientists in corresponding fields of knowledge from the countries of eastern and central Europe (Poland, Czechoslovakia, Bulgaria and the German Democratic Republic), countries of Western Europe (France, the Federal Republic of Germany and Austria) and Northern America (Canada). The fact that Professor V.S. Preobrazhensky was included in the working group as the USSR representative showed the appreciation of Soviet school of recreational geography achievements.

The working group had several international meetings in Salzburg, Olomouc, Peterborough, Krakow and Zakopane, Belogradchik, where Soviet scientists took an active part. In 1976 the annual symposium of the working group was organized by the USSR Academy of Science Institute of Geography in Dombai (Northern Caucasus). The results of the symposium collection of works by the international collective of scientists, 'Current Problems of Recreational Geography' (Moscow, 1976), has been published.

Due to the working group activity, the Soviet scientists had the opportunity to get acquainted with current investigations in recreational geography and tourism geography around the world, western European countries in particular. Tourism and recreational studies in the USSR were very much influenced by the works of scientists from western Germany (mainly K. Ruppert and J. Maier) who worked at the intersection of tourism geography and leisure sociology and by the French school of studies (B. Barbier, G. Wackermann) in the field of regional tourism planning and urban recreational activity.

Owing to the working group, a very useful stage for exchanging views, knowledge and information, as well as for establishing personal contacts and links between the scientists of different countries, including the USSR and western European countries, has been established. The international meetings held by the group gave new creative impulses for 
further scientific research; the progress of the scientific work was summarized there.

Nowadays, similar forms of cooperation between Russian and western European scientists have got new drives for development. The number of international meetings is steadily increasing; the themes for discussions are becoming more diverse and the lists of their participants are being enriched. Well-known western European specialists are invited to Russia as workshop speakers and moderators, as presentation sections and expert panel leaders and so on.

The emphasis placed in tourism science and education in various Central and Eastern European countries and regions

Tourism and recreation studies are becoming an independent area of research in Russia. A wide range of schools and trends causes the complexity of the scientific systematization. One of the main and the most imperative problems that face the Russian scientists is the problem of theoretical apparatus. The subject of tourism studies is arranged within the tourism definition. But still there is no generally accepted definition of tourism. In some cases, tourism is considered to be a sort of economic activity; in others, a sphere of cross-cultural communication; in others, an option of leisure pastime, a form of migration or a form of travel with geographical meaning. This state of affairs is connected with tourism's multifaceted nature, as well as with the interdisciplinary character of tourism comprehension.

The multidisciplinary character of tourism studies in Russia can be proved by the variety of theses themes in tourism (Table 2). Looking at theses on tourism defended in 1985-2010, we can see that the applicants were awarded scientific degrees in 17 social and humanitarian, natural and technical branches of science. The major part $(86 \%)$ of theses was presented for $\mathrm{PhD}$ and Doctoral degrees in economics, pedagogy and geography.

As a type of economic activity, tourism in Russia is studied at the macro, meso and micro level. If we take the microeconomic level, attention is mainly paid to the economic entities running in tourism. At the meso level, studies on tourism's role and function in regional

Table 2. Multidisciplinary structure of tourism studies 1985-2010

\begin{tabular}{lll}
\hline Scientific disciplines & $\begin{array}{l}\text { Number of completed } \\
\text { dissertations }\end{array}$ & $\begin{array}{l}\text { \% of total dissertations } \\
\text { number }\end{array}$ \\
\hline Architecture & 29 & 2.0 \\
Biology and agricultural sciences & 30 & 2.1 \\
Geography & 140 & 10.0 \\
Geology and mineralogical sciences & 1 & 0.1 \\
Art studies & 1 & 0.1 \\
Cultural studies & 10 & 0.7 \\
Medicine & 4 & 0.2 \\
Native history & 25 & 2.0 \\
Pedagogical sciences & 331 & 23 \\
Political sciences & 3 & 0.2 \\
Psychology & 4 & 0.3 \\
Sociology & 32 & 2.3 \\
Technical sciences & 15 & 1.0 \\
Philology & 4 & 0.1 \\
Philosophy & 5 & 0.3 \\
Economy & 751 & 53.0 \\
Law & 25 & 2.0 \\
\hline TOTAL & 1410 & 100 \\
\hline
\end{tabular}

Source: (Dorofeev and Yakovleva, 2011). 
development prevail. At the macroeconomic level, the position and role of tourism in the Russian and global economy are discussed. Russian specialists also point out the institutionalization of tourism marketing and management as independent scientific areas. Nowadays, the scientific interest of Russian specialists in tourism management is concentrated mainly on the theoretical and methodological foundations of regional tourism and recreational complex administration, including strategies for their management. In marketing, the focal point is aimed at the elaboration of differentiated marketing strategies. A large number of works are devoted to economics and the administration of separate tourism industry branches (hotels and accommodation, transport) or certain types of tourism in Russia and in the world (cultural tourism, business tourism, ecotourism, agritourism, leisure tourism and so on).

\section{Conclusion}

Russia's experience gives multiple patterns of research and education integration in the field of tourism and recreation. Over time, they changed the character, the methods and intensity of this process. The foundation, the nature and course of integration (its scale, forms, etc.) were determined by the complex of factors, including the group of fundamental factors - political, economic, social, technological - with cross-cutting action. However, the content, the strength and direction of their impact over the past half-century have changed radically. Thus, the new content of political, economic, social and technological factors requires a rethinking of the entire paradigm of scientific and educational activities in tourism and leisure studies.

The arrangement of Soviet, later - Russian research and teaching school in the field of tourism and recreation had a complicated and controversial character. The geographical approach towards tourism studies now is concentrated mainly on the evaluation of the tourism potential of a territory (mostly its natural conditions, resources and transport accessibility) and on the spatial organization analysis of tourism and its certain types at different levels. In comparison, the pedagogical view on tourism studies in Russia focuses on theoretical foundations for continuous professional education and professional qualities required for specialists in tourism.

Scientific cooperation between the USSR and the socialist countries in tourism and leisure science and education helped to develop their topics and methods of studies up to the end of 1980s. At present, cooperation between scientists from Russia and the international academic community, including the Russian experts in international social research networks, IT development for remote research and educational activities and programs, has received a new impetus for growth.

Tourism and recreation studies are becoming an independent area of research in Russia. If the interdisciplinary character of tourism studies is widely acknowledged, the existence of a separate science on tourism, its subject area and name are still under discussion for a long time. By now there is a wide range of schools, movements, individual approaches towards recreation and tourism studies. The problem of their conceptual terminology is one of the central and most pressing problems facing Russian scientists. Their discussions help to unite the scientific and educational community of the country around the most significant research projects in tourism and recreation.

\section{References}

Aleksandrov, Y.N. (1974) Podgotovka $i$ provedenie ekskursii: metodicheskiye recommendatsii. Moskva: CIRB Turist.

Current Problems of Recreational Geography. Moscow, 1976.

Dolmatov, G.M. (1976) Problemy povysheniya obschei effectivnosti inostrannogo turisma v SSSR. Problemy inostrannogo turisma $v$ SSSR. Moskva, 1976. no. 1.

Dolzhenko, G.P. (2010) Turismologia, turismovedenie ili turistika, Trudi mezhdunarodnoi turistskoi akademii. Moskva, 2010. URL: http://gennadiydolzhenko.ru/a25.html (Accessed on 15.12.2011).

Dorofeev, A.A., Yakovleva S.I. (2011) Mezdisciplinarnye i regionalnye issledovaniya turisma $\mathrm{v}$ Rossii. Regionalnye issledovaniya, 2(32), 15-23. 
Drogov, I.A., Loginov L.M., Matyar V.N. (1983) Uchebno-tematicheskiye plany i programmy seminarov povyshenia kvalificatsii predsedatelei i chlenov komissii po vidam turisma i pazdelam raboty federatsii turisma. Moskva: CIRB Turist.

Dvornichenko, V.V. (1985) Razvitie turizma v SSSR (1917-1983). Moskva: CIRB Turist.

Federalnyi obrazovatelnyi standart vysshego professionalnogo obrazovaniya po napravleniju podgotovki 100400 Turism (2009) Moskva, Ministry of Education and Science of the Russian Federation decree, 489, October 28, 2009.

Fedotova, L.N. (1980) Inostrannyi turist kak istochnik informatsyi ob SSSR, Problemy inostrannogo turisma $v$ SSSR. Moskva, no. 3.

Fisenko, L.M. (1978) Nekotoryje aspecty effectivnosti informatsionnoekskursionnoi raboty $\mathrm{v}$ oblasti inostrannogo turizma v SSSR, Problemy inostrannogo turisma $v$ SSSR. Moskva, no. 2.

Geografia recreatsionnih system v SSSR (1980) Otvetstvennye redactory V.S.Preobrazhensky, V.M. Krivosheev. Moskva: Nauka.

Geograficheskiye problemy organizatsii otdyha $i$ turisma: tezisy doklada $k$ rabochemy soveschaniju (1969) Moskva.

Giezgała, J. (1974) Turizm v narodnom hozyaistve. Moskva: Progress.

Kachanov, V.S. (1988) Sistema upravlenija kachestvom turistsko-ekskursionnogo obsluzhivaniya. Uchebnoe posobie: Moskva.

Katznelson, M.D. (1977) Metodicheskiye rekomendatsii po proverke gotovnosti turistskoi gruppi k puteshestviju. Moskva: CIRB Turist.

Kvartalnov, V.A. (1986) Turizm - sputnik mira: sostoyanie i perspectivy razvitiya, Problemy inostrannogo turisma $v$ SSSR. Moskva, no. 6.

Lukoyanov, P.I. (1977) Metodicheskije recomendatsii po provedeniju seminarov turistskikh organizatorov. Moskva: CIRB Turist.

Mironenko, N.S. (1973) Recreatsionnoje rajonirovanije Chernomorskogo poberezhja (SSSR, Bolgariya,

Rumjiniya): dissertatsyja na soiskanie uchenoi stepeni kandidata geograficheskih nauk, Moskovskii gosudarstvennyi universitet imeni M.V. Lomonosova. Moskva.

Mironenko, N.S. (1987) Recreatsionnaja sreda zarubezhnyih evropeiskih ctran-chlenov SEV (printsypi $i$ metody socialnogeograficheskih issledovanii): dissertatsyja na soiskanie uchenoi stepeni doctora geograficheskih nauk / Moskovskii gosudarstvennyi universitet imeni M.V.Lomonosova. Moskva.

Mironenko, N.S., Tverdokhlebov I.T. (1981) Recreatsionnaya geografia. Moskva: isdatelstvo MGU.

Mishev, K., V.I. Popov, H. Tishkov, M. Daneva, M. Iordanova, St.Velev (1974) Territorialnyje prirodno-recreatsionnije resursy Chernomorskogo poberezhja Bolgarii. Moskva: Nauka.

National Academy of Tourism official site http://www.nat-moo.ru/about.html

Okishev, P.A. (2005) Osnovy turizmovedeniya. Tomsk: izdatelstvo TGU.

Pasechnyi, P.S., Fadeev, B.G. (1980) Osnovy organizatsii $i$ upravkenia samodeyatelnym turizmom. Moskva: CIRB Turist.

Podgotovka turistskikh obschestvennykh kadrov (Polozheniye, uchebnye plany i programmy) (1982) Moskva.

Recreatsionnaya geografia SSSR (aspekty razvitiya i razmescheniya)(1983). Pod redaktsiei Yu.S.Putrika, V.V.Sveshnikova. Moskva, MFGO.

Recreatsionnyje resursy SSSR: problemy ratsionalnogo ispolzovaniya (1990). Pod redaktsiei V.I.Kozlova. Moskva: Nauka.

Recreatsionnyje systemy (1986). Pod redaktsiei N.S. Mironenko, M.Bochvarova. Moskva, isdatelstvo MGU.

Ruppert, K., J. Maier (1970) Naherholungsraum und Naherholung verkehr: geographische Aspekte eines speziellen Freizeitverhaltens. Zur Geographie des Freizeitverhaltens: Beiträge zur Fremdenverkehrsgeographie. (= Münchner Studien zur Sozial- und Wirtschafts- geographie, Bd. 6. Kallmünz, Regensburg: Lassleben. 
Schkolnije ekskursii, ih znachenije $i$ organizatsiya (1910) Pod redaktsiei B.E. Raikova, G.N. Bocha. Sankt-Peterburg.

Sokolova, M.V. (2002) Istoriya turizma. Moskva: Masterstvo.

Schturmer Yu. A. (1980) Estestvennogeograficheskaya $i$ kraevedcheskaya podgotovka instruktorov-metodistov po turismu. Moskva: CIRB Turist.

Teoreticheskiye osnovy recreatsionnoi geografii (problemy konstruktivnoi geografii) (1975) Otvetstvennyi redactor V.S. Preobrazhensky. Moskva: Nauka.

Teoreticheskiye problemy recreatsionnoi geografii (1989) Pod redaktsiei Yu.A.Vedenina, I.V.Zorina. Moskva

Territorialnaya organizatsiya otdyha naseleniya Moskvy i Moskovskoi oblasti (1986) Pod redaktsiei V.S.Preobrazhenskogo. Moskva: Nauka.

Tverdokhlebov, I.T., N.S. Mironenko (1981) Problemy rekreatsionnogo rajonirovaniya, Acta Universitatis Carolinae Geographica 16(1), 33-47.
Usyskin, G.S. (2000) Ocherki istorii rossiiskogo turizma. Sankt-Peterburg: ITD Gerda.

Vedenin, Yu. (1977) Recreational activities as a basis for the formation of technological structures of spatial recreational systems (SRS). In: Proceedings of the 6th International Congress of speleology. Olomoic/CSSR, 1973, v. 7. Subsection Fs: Geography of tourism in the Karst. Praha.

Vodenska, M. (1978) Socialnoeconomicheskije factory formirovaniya territorialnoi organizatsii otdyha naseleniya Bolgarii: dissertatsyja na soiskanie uchenoi stepeni kandidata geograficheskih nauk, Institut geografii AN SSSR, Moskva, 1978.

Zorin, I.V., V.A. Kvartalnov (2001) Turistika. Moskva: Sovetsky sport. 